\title{
Foliar Spray of Validamycin A or Validoxylamine A Controls Tomato Fusarium Wilt
}

\author{
Ryo Ishikawa, Kentaro Shirouzu, Hideo Nakashita, Han-Young Lee, Takayuki Motoyama, \\ Isamu Yamaguchi, Tohru Teraoka, and Tsutomu Arie
}

First author: Agricultural Research Laboratories, Sumitomo Chemical Takeda Agro Company, Limited, Takarazuka, Hyogo 665-0051, Japan; second, seventh, and eighth authors: Laboratory of Plant Pathology, Tokyo University of Agriculture and Technology (TUAT), Fuchu, Tokyo 183-8509; and third, fourth, fifth, and sixth authors: The Institute of Physical and Chemical Research (RIKEN), Wako, Saitama, 351-0198, Japan.

Current address of R. Ishikawa: Sumitomo Chemical Co., Ltd., Kasai, Hyogo 675-2333, Japan.

Accepted for publication 22 June 2005.

\begin{abstract}
Ishikawa, R., Shirouzu, K., Nakashita, H., Lee, H.-Y., Motoyama, T., Yamaguchi, I., Teraoka, T., and Arie, T. 2005. Foliar spray of validamycin A or validoxylamine A controls tomato Fusarium wilt. Phytopathology 95:1209-1216.

Tomato wilt, caused by the soilborne fungus Fusarium oxysporum $\mathrm{f}$. sp. lycopersici, is effectively controlled by a foliar spray of validamycin A (VMA) or validoxylamine A (VAA) $(\geq 10 \mu \mathrm{g} / \mathrm{ml})$; however, neither VMA nor VAA is antifungal in vitro. In pot tests, the effect of a foliar application of VMA or VAA at $100 \mu \mathrm{g} / \mathrm{ml}$ lasted for 64 days. Plants

sprayed with VMA or VAA accumulated salicylic acid and had elevated expression of the systemic acquired resistance (SAR) marker genes P4 (PR-1), Tag (PR-2), and NP24 (PR-5). Foliar spray of VMA also controlled late blight and powdery mildew of tomato. The disease control by VMA and VAA lasted up to 64 days after treatment, was broad spectrum, and induced the expression of $P R$ genes, all essential indicators of SAR, suggesting that VMA and VAA are plant activators. The foliar application of plant activators is a novel control method for soilborne diseases and may provide an economically feasible alternative to soil fumigants such as methyl bromide.
\end{abstract}

Soilborne diseases are important biotic constraints in sustainable crop production systems because the complexity of the soil environment makes their control with chemical fungicides difficult. Fusarium vascular wilt is a soilborne disease caused by Fusarium oxysporum. Preplant soil fumigants such as methyl bromide (bromomethane) that have a broad spectrum of activity have been used extensively to protect high-value crops from soilborne pathogens. However, the Scientific Assessment of Ozone Depletion by the World Meteorological Organization (1998) has assigned methyl bromide an ozone depletion potential of 0.4 , which categorizes it as a "Class I" ozone-depleting substance (36). Consequently, according to the 1997 Montreal Protocol, methyl bromide production and usage are to be phased out in developed nations by the year 2005 and in developing nations in 2015 (41). Alternative methods for controlling soilborne diseases must be developed in order to replace methyl bromide while maintaining high levels of disease control.

Validamycin A (VMA) ([1S- $(1 \alpha, 4 \alpha, 5 \beta, 6 \alpha]-1,5,6$-trideoxy-4- $O$ $\beta$-D-glucopyranosyl -5-(hydroxymethyl)-1-[[4,5,6-trihydroxy-3(hydroxymethyl)-2-cyclohexen-1-yl] amino]-D-chiro-inositol-1L$(1,3,4 / 2,6)-2,3$-dihydroxy-6-hydroxymethyl-4-[(1S,4R,5S,6S)4,5,6-trihydroxy-3-hydroxymethylcyclohex-2-enylamino]cyclohexyl-3-D-glucopyranoside) is an aminoglucoside antibiotic produced by Streptomyces hygroscopicus var. limoneus (1). VMA effectively controls rice sheath blight caused by Rhizoctonia solani (38). Validoxylamine A (VAA) ([1S-( $1 \alpha, 4 \alpha, 5 \beta, 6 \alpha)]-1,5,6$-trideoxy5-(hydroxymethyl)-1- [[4,5,6-trihydroxy-3-(hydroxymethyl)-2cyclohexen-1-yl]amino]-D-chiro-inositol), which is an aglycon of VMA, carries $\alpha, \alpha$-trehalase, a trehalose-degrading enzyme, in-

Corresponding author: T. Arie; E-mail address: arie @cc.tuat.ac.jp

DOI: 10.1094/PHYTO-95-1209

() 2005 The American Phytopathological Society hibitory activity (1,32). VMA is considered to be easily deglucosidated to VAA in plants (32). Trehalose is a nonreducing disaccharide of glucose that functions as a compatible solute in the stabilization of biological structures under abiotic stress in bacteria, fungi, plants, and invertebrates (9). It also functions as transportable or storage carbohydrates in bacteria, fungi, and plants. Especially, trehalose is the sole transportable carbohydrate in $R$. solani (33), and inhibition of trehalase by VAA leads to the accumulation of trehalose in hyphae, reduces the level of utilizable carbohydrate in hyphal tips, and suppresses hyphal elongation (33) on rice leaves. VMA is fungistatic but not fungicidal against $R$. solani. A spray of trehalose at a high concentration controlled powdery mildew in wheat (29). These results could be correlated to modifications of carbohydrate metabolism $(7,31)$.

VMA is harmless to mammals and fish; the $50 \%$ lethal dose $\left(\mathrm{LD}_{50}\right)$ for rats is $20 \mathrm{~g} / \mathrm{kg}$ (35). VMA is degraded rapidly in soil, with a half-life of $<5 \mathrm{~h}$ (35). The United States Environmental Protection Agency (EPA) has classified VMA into the toxicity class IV, or practically nontoxic (35). In Asia and Europe, more than 300 tons of VMA are used annually. There has been no report of the occurrence of VMA-resistant $R$. solani although VMA has been used in Japan for the control of rice sheath blight for more than 30 years.

Ishikawa et al. (12-14) reported that VMA was effective against bacterial plant diseases such as cabbage black rot, Chinese cabbage soft rot, and lettuce bacterial rot. VMA has antibacterial activity against Xanthomonas campestris pv. campestris, the casual agent of cabbage black rot, but only when the bacterium is grown on a medium containing trehalose as the sole carbohydrate source (14). Pseudomonas cichorii, a lettuce bacterial rot pathogen, cannot metabolize trehalose (23). Thus, VMA likely has another mode of action with respect to the control of this pathogen. This mode of action may involve the activation of plant defense responses. 
The objective of this study was to determine whether a foliar spray of VMA or VAA was effective in controlling tomato $\mathrm{Fu}-$ sarium wilt, a major worldwide soilborne disease. We also examined whether VMA or VAA are plant activators which induce systemic acquired resistance (SAR), signaling cascade in treated tomato plants.

\section{MATERIALS AND METHODS}

Plants. Tomato (Lycopersicon esculentum Mill.) cultivars used in the experiments are listed in Table 1. Tomato seed were sown in sterilized soil in $9-\mathrm{cm}$ plastic pots, and then the plants were grown in a growth chamber with light and dark intervals of $16 \mathrm{~h}$ of light at $28^{\circ} \mathrm{C}$ and $8 \mathrm{~h}$ of darkness at $25^{\circ} \mathrm{C}$ for 28 days until treatment. For the large-scale pot test, 14-day-old tomato seedlings were transplanted into infested soil in a $200-\mathrm{cm}^{2}$ plastic pot (1/5,000 Wagner pot; Kiya Seisakusho, Kawagoe, Saitama, Japan) (8).

Fungal strain and culture conditions. Fusarium oxysporum $\mathrm{f}$. sp. lycopersici race 2 isolate 880621a-1 (=JCM 12575) was the major strain used in these experiments. F. oxysporum f. sp. lycopersici race 3 F-1-1 (gift from Y. Hosobuchi, Sakata Seed, Yokohama, Kanagawa, Japan) was used for tomato cultivars resistant to race 2 (Table $1, I-2$ ). F. oxysporum f. sp. lycopersici isolates were maintained on potato dextrose agar (PDA) (Difco Laboratories, Detroit) at $28^{\circ} \mathrm{C}$. F. oxysporum f. sp. lycopersici isolates were cultured on potato dextrose broth (PDB) (Difco Laboratories) at $28^{\circ} \mathrm{C}$ with a reciprocal shaker $(120 \mathrm{rpm})$ for 4 days, and the spore (bud cell) suspension (adjusted to 1 to $2 \times$ $10^{7}$ spores $/ \mathrm{ml}$ ) was used as the inoculum.

Tomato plants were infected naturally with Oidium spp., the casual agent of tomato powdery mildew, in a greenhouse (15). The casual agent of tomato late blight, Phytophthora infestans isolate TKF-411, was maintained on detached tomato (cv. Odoriko) leaves under humid and dark conditions at $20^{\circ} \mathrm{C}$. The sporangium suspension ( 1 to $2 \times 10^{4}$ zoosporangia/ml) was prepared by washing the leaves in sterilized water and used as the inoculum.

Chemicals. VMA (MW 497.5), VAA (MW 335.4), probenazole (PBZ, MW 237.3), and a benzothiadiazole derivative, acibenzolar-S-methyl (ASM, MW 210.3) used in the experiments were 99\% purity grade. PBZ and ASM were kindly provided by Meiji Seika Kaisha (Tokyo) and Syngenta Japan (Tokyo), respectively. Trehalose ( $\alpha$-D-glucopyranosyl-[1,1]- $\alpha$-D-glucopyranoside) was purchased from Sigma-Aldrich Japan (Tokyo). VMA, VAA, and trehalose were dissolved in water. PBZ and ASM were dissolved in $1 \%(\mathrm{vol} / \mathrm{vol}) \mathrm{N}, \mathrm{N}$-dimethyformamide and then diluted with water.

Pot test for control of Fusarium wilt of tomato. Chemical solutions were sprayed with an air-powered sprayer at $78 \mathrm{kPa}$ onto the foliage of 28-day-old tomato plants, usually 7 days before challenging by the pathogen. After a few hours in the ambient atmosphere for drying the foliar surfaces, the plants were maintained in a growth chamber.

Tomato plants were inoculated with $F$. oxysporum f. sp. lycopersici as described by Kawabe et al. (16). Briefly, the roots were partially cut by inserting a plastic peg into the soil and $5 \mathrm{ml}$ of $F$. oxysporum f. sp. lycopersici inoculum was poured into the potted soil. The same plant growth conditions were used before and after plant inoculation. After 28 days, the disease index (on a scale of 0 to 4 ) on each plant was recorded according to vascular browning (19) and the mean value was calculated as the disease severity. For evaluation of vascular browning, the stem of each plant was cut at the soil line and vascular browning was rated on a scale where $0=$ healthy, $1=25 \%$ browning, $2=50 \%$ browning, $3=75 \%$ browning, and $4=100 \%$ browning.

For the large-scale pot test, 14-day-old tomato (cv. Odoriko) seedlings were transplanted into $200-\mathrm{cm}^{2}$ pots filled with soil infested with $F$. oxysporum f. sp. lycopersici (27). The same plant growth conditions were used before and after transplanting. Tomato plants were sprayed three times with VMA solution at 10 or $20 \mu \mathrm{g} / \mathrm{ml}$ at 0,14 , and 27 days after transplant. The disease index of each plant was recorded 64 days after transplant according to the wilt symptom and vascular browning (19) and the mean value was calculated as the disease severity. For evaluation of wilt symptom, each plant was observed and rated as follows: $0=$ no symptoms, $1=25 \%$ plant wilting, $2=50 \%$ wilting, $3=75 \%$ wilting, and $4=$ whole plant wilting.

Test for control of powdery mildew and late blight of tomato. To evaluate VMA efficacy for control of powdery mildew, we transplanted 14-day-old tomato (cv. Odoriko) seedlings to the soil in a greenhouse. The plants were sprayed twice ( 0 and 14 days after transplant) with VMA at $10 \mu \mathrm{g} / \mathrm{ml}$. The plants in the greenhouse were naturally infected with Oidium spp. (15). Visible diseased area (powdery spot of whitish conidiophores and conidia) on the third to eighth leaves was rated 50 days after the last spray from 0 to $100 \%$ in $5 \%$ increments according to Ohata et al. (27). The average percentage of diseased area was calculated (27). In each plot, three replicates with six plants were used.

To determine the time until the resistance against powdery mildew was expressed after treatment, we inoculated the tomato (cv. Odoriko) plants with conidia of Oidium spp. by tapping dis-

TABLE 1. Control of Fusarium wilt of tomato cultivars with foliar spray of validamycin A (VMA) or validoxylamine A (VAA) at $100 \mu \mathrm{g} / \mathrm{ml}$

\begin{tabular}{|c|c|c|c|c|c|c|c|c|c|}
\hline \multirow[b]{3}{*}{ Cultivar $^{v}$} & \multirow[b]{3}{*}{ Resistance $^{\mathrm{W}}$} & \multirow[b]{3}{*}{$\operatorname{Race}^{\mathrm{x}}$} & \multirow[b]{3}{*}{ Seed $^{\mathrm{y}}$} & \multicolumn{6}{|c|}{ Vascular browning $^{\mathrm{z}}$} \\
\hline & & & & \multicolumn{4}{|c|}{ Disease severity $\pm \mathrm{SE}$} & \multicolumn{2}{|c|}{ Control (\%) } \\
\hline & & & & Healthy & Mock & VMA & VAA & VMA & VAA \\
\hline Ponderosa & $i i-2$ & 2 & 1 & $0.0 \pm 0.0$ & $2.7 \pm 1.2 b$ & $0.8 \pm 0.7 \mathrm{a}$ & $0.0 \pm 0.0 \mathrm{a}$ & 70.4 & 100.0 \\
\hline Momotaro & $I i-2$ & 2 & 2 & $0.0 \pm 0.0$ & $3.6 \pm 0.7 b$ & $2.3 \pm 1.1 \mathrm{a}$ & $1.4 \pm 0.7 \mathrm{a}$ & 36.1 & 61.1 \\
\hline Odoriko & $I i-2$ & 2 & 3 & $0.0 \pm 0.0$ & $2.7 \pm 1.4 \mathrm{~b}$ & $0.0 \pm 0.0 \mathrm{a}$ & $0.5 \pm 0.8 \mathrm{a}$ & 100.0 & 81.5 \\
\hline Sun Road & $I i-2$ & 2 & 3 & $0.0 \pm 0.0$ & $3.2 \pm 1.2 \mathrm{~b}$ & $0.7 \pm 0.7 \mathrm{a}$ & $0.7 \pm 1.0 \mathrm{a}$ & 78.1 & 78.1 \\
\hline Kijuku-Tougyoku 2 & $I I-2$ & 3 & 4 & $0.0 \pm 0.0$ & $3.3 \pm 1.3 b$ & $0.2 \pm 0.4 \mathrm{a}$ & $0.0 \pm 0.0 \mathrm{a}$ & 93.9 & 100.0 \\
\hline Scrum & $I I-2$ & 3 & 2 & $0.0 \pm 0.0$ & $1.1 \pm 0.6 \mathrm{~b}$ & $0.2 \pm 0.4 \mathrm{a}$ & $0.0 \pm 0.0 \mathrm{a}$ & 81.8 & 100.0 \\
\hline
\end{tabular}

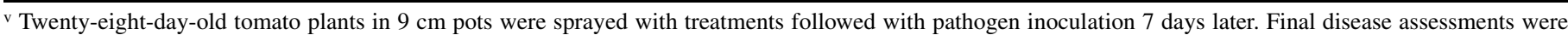
made on 56-day-old plants. At least six plants were used in each treatment.

${ }^{w}$ All the cultivars except Ponderosa were F1; $i$ - 2 , carrying no resistant genes; $I i$-2, resistance gene $I$; and $I I$-2, resistant genes $I$ and $I$ - 2 .

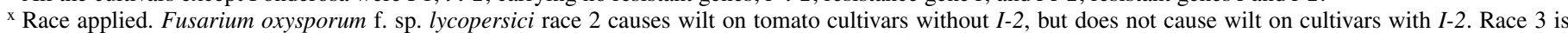
pathogenic to all tomato cultivars tested.

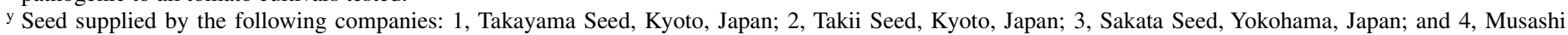
Seed, Nerima, Tokyo.

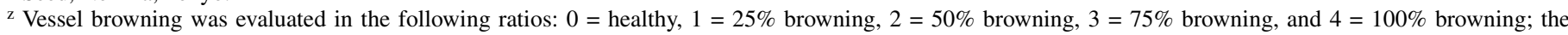
mean value of six samples is presented as disease severity with the standard error (SE). Different letters after the numbers indicate a significant difference between treatments for each cultivar according to Tukey's honestly significant difference $(P<0.05)$. The experiments were repeated three times and similar results were obtained. 
eased tomato leaves with a white powdery layer of conidia on the surface $\approx 30 \mathrm{~cm}$ above the healthy plants 1 to 7 days after VMA treatment. This method provided distribution of conidia at a density of $\approx 10^{2}$ to $10^{3}$ spores $/ \mathrm{cm}^{2}$ of leaf. Visible diseased area on the first to fifth leaves was rated from 0 to $100 \%$ in $5 \%$ increments 10 days after inoculation, and the average percentage of the diseased area was calculated. In each treatment, 10 plants with three replicates were used.

To determine VMA efficacy on control of late blight, we sprayed 28-day-old tomato (cv. Odoriko) plants, grown in pots and maintained in a growth chamber with VMA $(100 \mu \mathrm{g} / \mathrm{ml})$. Seven days after treatment, one drop of sporangium suspension $\left(1 \times 10^{4}\right.$ zoosporangia/ml) of $P$. infestans was placed on the first leaf. Inoculated tomato plants then were grown at $20^{\circ} \mathrm{C}$ in a highhumidity $(\approx 80 \%)$ chamber with light and dark intervals of 16 and $8 \mathrm{~h}$, respectively. Mist from the humidifier splashed the sporangia to upper leaves. Fourteen days after inoculation, the percentage of disease area (lesion and white sporulation of sporangiophores and sporangia) was estimated from 0 to $100 \%$ in $5 \%$ increments (27). In each plot, eight plants were used and three trials were done.

Antifungal activity assay in vitro. VMA and VAA were dissolved in water, sterilized through $0.22-\mu \mathrm{m}$-pore membrane filters (Millipore, Billerica, MA), and mixed at a final concentration of $100 \mu \mathrm{g} / \mathrm{ml}$ with Czapek agar containing trehalose, sucrose, or glucose as the sole carbohydrate; with PDA; or with water agar. A mycelial disk, $4 \mathrm{~mm}$ in diameter, was taken from the edge of a colony of $F$. oxysporum f. sp. lycopersici grown on PDA at $28^{\circ} \mathrm{C}$ for 5 days, and was placed on each test medium and incubated at $28^{\circ} \mathrm{C}$ for 4 days. The diameter of the subsequent colony was measured and recorded. Three separate experiments were conducted with six replicates for each treatment.

Extraction and analysis of endogenous salicylic acid. Leaves of 28-day-old tomato (cv. Odoriko) plants were sprayed with VMA or VAA at $100 \mu \mathrm{g} / \mathrm{ml}$, or with the same amount of water to serve as a control. PBZ, a SAR inducer, at $100 \mu \mathrm{g} / \mathrm{ml}$, served as a positive control. The plants were grown in a growth chamber until used. Leaves or roots ( 1 to $2 \mathrm{~g}$ ) were collected, soaked in 10 times their volume per weight of $2 \%(\mathrm{vol} / \mathrm{vol})$ acetic acid $(\mathrm{pH} 2.7)$, and boiled for $10 \mathrm{~min}(3,26)$. Boiling under an acidic condition hydrolyzes conjugated salicylic acid (SA) to free SA and glucose (3). Therefore, the amount of SA detected by high-performance liquid chromatography (HPLC) in this study indicates the total amount of free and conjugated SA in tomato tissue.

The concentration of SA in the solution was measured by HPLC. The extract was injected into a C-18 column (Shim-Pack CLC-ODS; Shimadzu, Kyoto, Japan) in 50\% (vol/vol) methanol containing $0.05 \%$ (vol/vol) phosphoric acid and was eluted at $1 \mathrm{ml} / \mathrm{min}$ at $40^{\circ} \mathrm{C}(26)$. SA was detected with a fluorescence detector (excitation $290 \mathrm{~nm}$, emission $402 \mathrm{~nm}$ ), or UV detector at $245 \mathrm{~nm}$.

RNA extraction and northern blot analysis. Leaves (100 mg) from tomato plants (cv. Odoriko) prepared in the same manner as described earlier were harvested at 7 days after treatment. Leaves were homogenized in liquid nitrogen with biological grinding beads (Roche, Basel, Switzerland), and total RNA was extracted from the samples using Isogen-LS reagent (Roche) following the manufacturer's protocol.

To generate probes for northern blots, we amplified DNA fragments of the P4 (PR-1; M69247) (37), tomato acidic glucanase (Tag, PR-2; M80604) (37), and tomato osmotin (Tos, PR-5; M21346) (18) genes by the polymerase chain reaction (PCR) from genomic DNA of tomato plants (cv. Odoriko). A P4-specific primer pair (Tomp4-1, 5'-CCAAAATTCACCCAAGACT-3' and Tomp4-2, 5'-ACGAGCCCGACCACAACCTA-3') yielded PCR products of 334 bp. A Tag-specific primer pair (TomAGL3, 5'ATACGCACGATTTGTTGGTC-3' and TomAGL4, 5'-AGTCCTTCCTGGTTTCTTTG-3') yielded PCR products of $512 \mathrm{bp}$. A Tos-specific primer pair (Tos-1, 5'-CTTATGCTGCCACTATTG-
AG-3' and Tos-2, 5'-GGATCAGCAACACCATTAGG-3') yielded PCR products of $640 \mathrm{bp}$. PCR products were cloned into a pGEM-T Easy vector (Promega Corp., Madison, WI), respectively. ${ }^{32} \mathrm{P}$-labeled DNA probes were prepared by random priming.

Total RNA from the tomato plants was separated by $1.2 \%$ (wt/vol) agarose-5\% (vol/vol) formaldehyde gel electrophoresis and transferred to a Hybond $\mathrm{N}+$ nylon membrane (Amersham Biosciences, Uppsala, Sweden). After the transfer, the RNA was fixed to the membrane using a UV cross-linker. The blotted membrane was prehybridized, hybridized with the probes, washed as described by Church and Gilbert (5), and visualized using BAS2500 (Fuji Photo Film, Tokyo).

Statistical analyses. All statistical analyses were done with JMP software (version 5.0.1J; SAS Institute, Tokyo). Differences in means were tested using the post hoc multiple comparison test, Tukey's honestly significant difference (HSD; $P<0.05$ ).

\section{RESULTS}

Control of tomato Fusarium wilt by foliar application of VMA or VAA in pot tests. VMA and VAA at $100 \mu \mathrm{g} / \mathrm{ml}$ controlled Fusarium wilt of tomato (cv. Odoriko) caused by $F$. oxysporum f. sp. lycopersici by foliar spray in a pot test. A foliar spray of VMA or VAA controlled $>80 \%$ of the internal symptoms of the disease when $F$. oxysporum f. sp. lycopersici was inoculated 7 or 21 days after treatment (Fig. 1A and B). The foliar spray of ASM at $100 \mu \mathrm{g} / \mathrm{ml}$ (benzo [1,2,3]thiazole-7-carbothioic acid $S$-methyl ester) or PBZ at $100 \mu \mathrm{g} / \mathrm{ml}$ (3-allyloxy-1,2-benzoisothiazole-1,1-dioxide), both of which are known plant activators $(2,11,13,20,22)$, showed a lower efficacy (Fig. 1A and B). The mean heights of noninoculated tomato plants treated with VMA or VAA at $100 \mu \mathrm{g} / \mathrm{ml}$ were $\approx 20 \%$ shorter than those of control plants 42 days after treatment (Fig. 1C). This growth reduction also was observed in tomato plants treated with foliar spray of another plant activator, ASM (Fig. 1C).

The foliage of several tomato cultivars in pots was sprayed with VMA or VAA to determine whether the observed effects were cultivar dependent (Table 1). Four of the six cultivars were susceptible to F. oxysporum f. sp. lycopersici race $2880621 \mathrm{a}-1$, and two cultivars (Kijyuku-Togyoku and Scrum) were resistant to race 2 but susceptible to race 3 F-1-1 (Table 1). On all tomato cultivars tested, foliar application with VMA or VAA significantly inhibited the vascular browning typical of Fusarium wilt (Table 1). The protection values varied among cultivars, suggesting that the difference may depend on the quantity or quality of resistance gene expression in each cultivar.

Control of tomato Fusarium wilt by foliar spray of VMA in large-scale pot experiment. We sprayed VMA onto 14-day-old tomato plants (cv. Odoriko) and transplanted them to $200-\mathrm{cm}^{2}$ pots filled with soil infested with $F$. oxysporum f. sp. lycopersici race 2. VMA was sprayed on the foliage three times at 14-day intervals. VMA at 10 or $20 \mu \mathrm{g} / \mathrm{ml}$ inhibited $60 \%$ of the vascular browning compared with the water-sprayed plants $\approx 64$ days after transplanting (Table 2). The length of the basal petiole in the seventh leaf sprayed with VMA was $>30 \%$ smaller than those of the water-sprayed plants (Table 2).

Inhibition of mycelial growth in vitro. VMA or VAA at $100 \mu \mathrm{g} / \mathrm{ml}$ did not inhibit the mycelial growth of $F$. oxysporum $\mathrm{f}$. sp. lycopersici on PDA, water agar, or Czapek agar containing trehalose, sucrose, or glucose as the sole carbohydrate source (Table 3), indicating that VMA and VAA did not have antifungal activity on $F$. oxysporum f. sp. lycopersici.

Increased SA accumulation in tomato leaves by foliar spray of VMA. Foliar spray with VMA, VAA, or PBZ enhanced the accumulation of SA or conjugated SA in tomato (cv. Odoriko) leaves 5 days after treatment (Fig. 2). The level of SA in the leaves of tomato plants sprayed with VMA, VAA, or PBZ at $100 \mu \mathrm{g} / \mathrm{ml}$ was $15.9-, 15.5-$, and 8.1-fold higher, respectively, than 
that in the leaves of water-sprayed tomato. SA in the leaves began accumulating 3 days after foliar spray of VMA and VAA (Fig. 3). SA accumulation reached a peak 5 days after treatment and, thereafter, the amount of SA was $\approx 0.1$ to $0.2 \mu \mathrm{g} / \mathrm{ml}$ up to 14 days
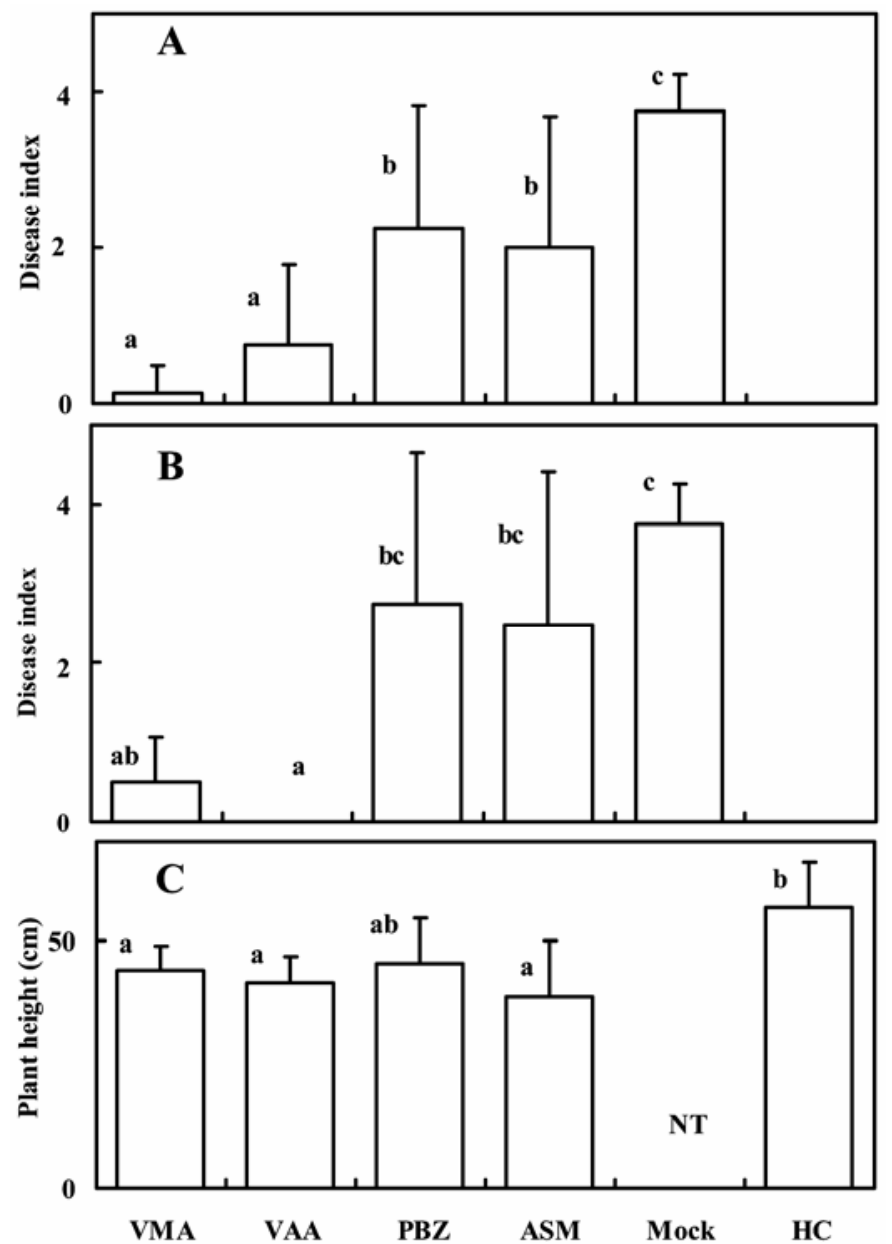

Fig. 1. Control of tomato Fusarium wilt by foliar spray with validamycin A (VMA) or validoxylamine A (VAA) and effect of treatment on plant height. Tomato plants (cv. Odoriko, 28 days old) were inoculated with Fusarium oxysporum f. sp. lycopersici $\mathbf{A}, 7$ and $\mathbf{B}, 21$ days after treatment. C, Heights of plants treated with chemicals were measured 42 days after treatment. At least eight plants were used in each treatment. $\mathrm{PBZ}=$ probenazole, $\mathrm{ASM}=$ acibenzolar- $S$-methyl, Mock = water spray, $\mathrm{HC}=$ control without inoculation. After a 28-day incubation, tomato basal stems were cut and vessel browning of each individual was evaluated on a scale where $0=$ healthy, $1=25 \%$ browning, $2=50 \%$ browning, $3=75 \%$ browning, and $4=100 \%$ browning. The bar represents the standard error. Letters above a column indicate significant difference according to Tukey's honestly significant difference $(P<$ $0.05) ; \mathrm{NT}=$ not tested. The experiments were repeated three times with similar results. after treatment. SA accumulation was greater in the upper leaves compared with the sprayed leaves with VMA and VAA (Fig. 2). On the other hand, PBZ enhanced the accumulation of SA only in the treated leaves, not in the upper leaves. In roots of tomato plants treated with foliar sprays of VMA or VAA, the SA concentration was below the detection limit of the technique used $(0.05 \mu \mathrm{g} / \mathrm{g}$ of fresh weight).

$P R$ genes expression in tomato plants after foliar spray with VMA. In northern blot analysis, transcription of SAR marker genes (PR-1, P4; PR-2, Tag; and PR-5, Tos) was enhanced in the leaves from tomato plants treated by foliar spray with either VMA or VAA $(100 \mu \mathrm{g} / \mathrm{ml})$ (Fig. 4). ASM $(125 \mu \mathrm{g} / \mathrm{ml})$ was equally effective in inducing P4, Tag, and Tos expression. By contrast, no transcripts were detected in water-treated leaves of control tomato plants. These findings suggested that VMA and VAA were chemical inducers of SAR.

Control of foliar diseases of tomato plants by foliar spray of VMA. We examined whether a foliar spray of VMA controls other diseases of tomato as well. A foliar spray of VMA at $10 \mu \mathrm{g} / \mathrm{ml}$ or higher reduced powdery mildew of tomato caused by Oidium spp. in the greenhouse 50 days after treatment (Table 4). Although a foliar spray of VMA at $100 \mu \mathrm{g} / \mathrm{ml} 4$ to 7 days before inoculation controlled powdery mildew, a foliar spray of VMA 1 to 3 days before inoculation did not control the disease (Table 5). The disease was not controlled by the foliar spray of trehalose at $100 \mu \mathrm{g} / \mathrm{ml}$ (Table 5).

VMA treatments prior to inoculation also controlled tomato late blight caused by $P$. infestans in pot tests (Table 4). Diseased areas on the leaves of water-sprayed tomato plants comprised 67 to $87 \%$, whereas that on leaves sprayed with VMA at $100 \mu \mathrm{g} / \mathrm{ml}$ comprised 17 to $27 \%$ of the total area, which indicated 60 to $72 \%$ protection (Table 4). VAA controlled the disease as well as VMA (Table 4). VMA or VAA was neither fungicidal nor fungistatic against $P$. infestans in vitro (R. Ishikawa and T. Arie, unpublished data).

\section{DISCUSSION}

Historically, soil has been fumigated with chemicals for control of soilborne diseases (4). The vascular wilt fungus $F$. oxysporum is a soilborne facultative parasite that causes economically important losses in a wide variety of crops. F. oxysporum f. sp. lycopersici causes severe wilt of tomato and, in some cases, causes destructive losses in tomato production. The use of $\mathrm{Fu}$ sarium spp.-resistant tomato cultivars can provide some degree of control of Fusarium wilt. Although several fungicidal chemicals, such as chlorothalonil, have been tried for controlling diseases by soil drenching with aqueous solution or mixing their powdery form with soil, the efficacies were not as high as expected (13). This might be due to the active compounds being adsorbed to soil particles or degraded by soil microorganisms, or to the difficultto-reach pathogens in soil. Given the total volume of soil that

TABLE 2. Control of Fusarium wilt of tomato plants by foliar spray of validamycin A (VMA) in a large-scale pot test ${ }^{\mathrm{w}}$

\begin{tabular}{|c|c|c|c|c|c|c|}
\hline \multirow[b]{2}{*}{ Treatment $^{\mathrm{x}}$} & \multicolumn{2}{|c|}{ Wilt $^{\mathrm{y}}$} & \multicolumn{2}{|c|}{ Vascular browning $^{\mathrm{z}}$} & \multicolumn{2}{|c|}{ Length of seventh leaf petiole } \\
\hline & Disease severity $\pm \mathrm{SE}$ & Protection $(\%)$ & Disease severity $\pm \mathrm{SE}$ & Protection $(\%)$ & Length $\pm \mathrm{SE}(\mathrm{cm})$ & Reduction (\%) \\
\hline Mock & $2.3 \pm 1.3 \mathrm{~b}$ & & $2.5 \pm 0.6 b$ & & $44.8 \pm 1.1 \mathrm{c}$ & \\
\hline
\end{tabular}

${ }^{\mathrm{w}}$ Different letters after the numbers in each column indicate a significant difference according to Tukey's honestly significant difference $(P<0.05)$. The experiments were repeated three times with similar results.

${ }^{\mathrm{x}}$ Fourteen-day-old tomato plants (cv. Odoriko) in $9 \mathrm{~cm}$ pots were sprayed with VMA at $10 \mathrm{or} 20 \mu \mathrm{g} / \mathrm{ml}$ at 14, 28, 41 days after seeding. The tomato plants were transplanted to infested soil in $200-\mathrm{cm}^{2}$ pots $4 \mathrm{~h}$ after the first spray. Final disease assessments were made on 78 -day-old plants.

${ }^{y}$ External symptoms of wilt were observed in the following ratios: 0 = healthy, $1=$ yellowing, $2=$ yellowing and wilting, $3=$ wilting of the whole plant, and $4=$ dead. The numbers represent the average disease severity with standard error (SE) of at least eight tomato plants.

${ }^{\mathrm{z}}$ Vessel browning of each individual was evaluated in the following ratios: $0=$ healthy, $1=25 \%$ browning, $2=50 \%$ browning, $3=75 \%$ browning, and $4=100 \%$ browning. The numbers represent the average disease severity with SE of at least eight tomato plants. 
would need to be treated and the expense associated with fumigation, foliar spray would be the most feasible method to control soilborne diseases. Recently, several plant activators, such as ASM (2,10,11), PBZ (44), and harpin (39), all of which induce SAR in plants, have received much attention because they control a wide range of diseases and their efficacy is of long duration $(28,30,34)$. However, there have been only two reports $(2,11)$ about plant disease resistance inducing compounds effective against soilborne wilt pathogens. In this study, foliar sprays of VMA or VAA effectively controlled Fusarium wilt of tomato caused by $F$. oxysporum f. sp. lycopersici. VMA and VAA lack anti-F. oxysporum f. sp. lycopersici activity in vitro and, thus, may work as plant activators on tomato because they have several qualities characteristic of SAR inducers (17) - they have no fungicidal activity against the pathogens (Table 3 ); they induce a broad range of disease resistance (Tables 1 and 4); the resistance lasts for a long period (Fig. 1; Table 4); they induce several SAR molecular markers, such as SA accumulation and $P R$ gene expression (Figs. 3 and 4); and they need a time lag between treatment and expression of efficacy (Table 5). However, SA accumulation was not detected in roots of tomato that were treated with a foliar spray of VMA; therefore, whether or not the efficacy of VMA against Fusarium wilt arises from SAR has yet to be clarified.

Pathogen-induced SAR usually is associated with a significant and sustained increase of free or total SA in the tissue $(6,42) .1,2-$ Benzisothiazol-3 (2H)-one 1,1-dioxide (BIT), a metabolite of PBZ, induced the accumulation of total SA in Arabidopsis spp., but did not induce accumulation of free SA (43). Free SA accumulates transiently followed by a sustained increase in the conjugated SA level (21). In Arabidopsis spp., $>80 \%$ of acidreleasable SA was recovered after $\beta$-glucosidase treatment (3). In this study, we extracted acid-releasable SA from tomato leaves by boiling them in $2 \%$ acetic acid $(\mathrm{pH} 2.7)$. Acid-releasable SA contains free SA and conjugated SA, mainly composed of glucosidated SA. Enhancement of the accumulation of acid-releasable SA in tomato by foliar spray of VMA or VAA (Fig. 2) suggested that the chemicals stimulated the region upstream of SA in the SAR signal transduction pathway, as PBZ does (44). The level of acid-releasable SA in upper leaves treated with VMA or VAA exceeded that of the plants treated with PBZ (Fig. 2). Although PBZ enhanced the accumulation of SA mainly in treated leaves 5 days after foliar treatment, VMA and VAA enhanced SA accumulation more in the upper leaves than the treated leaves (Fig. 2). These results might be due to the differences in modes of chemical translocation in plants. PBZ might stay in treated leaves because it is slightly soluble in water $(\approx 150 \mathrm{mg} / \mathrm{liter})$, which resulted in accumulation of SA in sprayed leaves. On the other hand, VMA and VAA translocated to the upper leaves because they are readily soluble in water (35), which may result in accumulation of more SA in upper leaves than in sprayed leaves. Foliar spray of VMA or VAA controlled F. oxysporum f. sp. lycopersici, a soilborne pathogen, and induction of SAR in VMA- or VAA-treated tomato roots was suspected. Experiments to extract and qualify the acid-releasable SA in tomato roots were conducted, but none was detected (detection limit of the technique used was $0.05 \mu \mathrm{g} / \mathrm{g}$ of fresh weight). These findings suggested that, in roots, resistance other than SAR is induced, or that

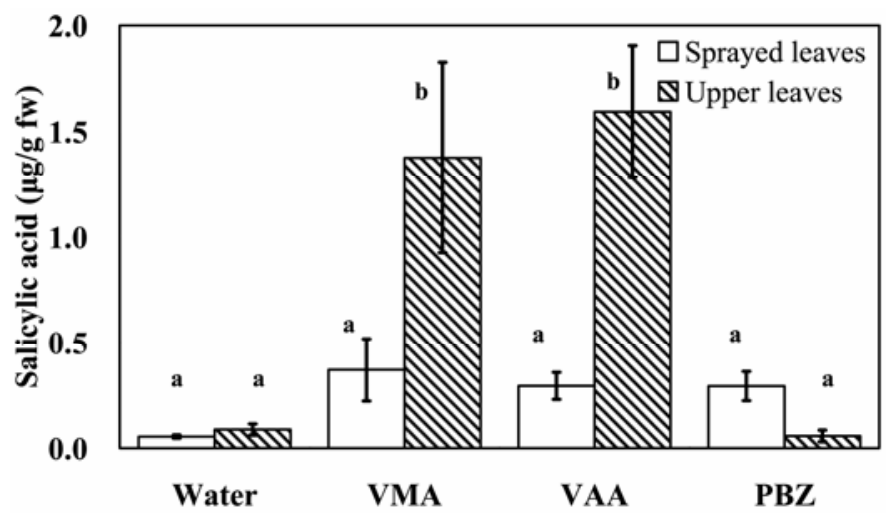

Fig. 2. Endogenous salicylic acid (SA) in sprayed leaves and upper leaves of tomato plants. Validamycin A (VMA), validoxylamine A (VAA), or probenazole (PBZ) was sprayed at $100 \mu \mathrm{g} / \mathrm{ml}$ on leaves of tomato plants (cv. Odoriko) 28 days after seeding. Third and fourth leaves (sprayed leaves, white bars), and sixth and seventh leaves (upper leaves, shaded bars) were collected separately 5 days after treatment. Free SA was estimated by high-performance liquid chromatography and quantified with a fluorescence detector (excitation $290 \mathrm{~nm}$, emission $402 \mathrm{~nm}$ ). Bars indicate standard errors. Letters above a column indicate significant difference according to Tukey's honestly significant difference $(P<0.05)$. The experiments were repeated three times with similar results.

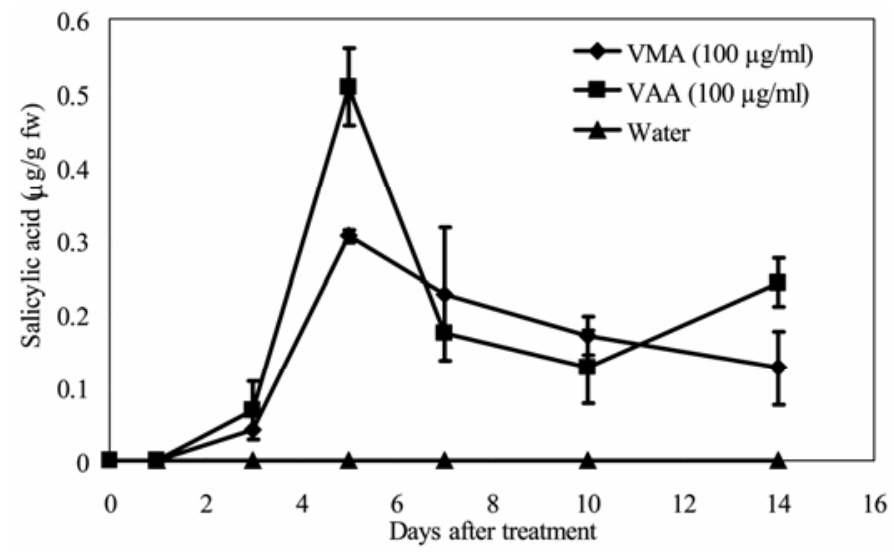

Fig. 3. Accumulation of total salicylic acid (SA) in tomato leaves sprayed with validamycin A (VMA) or validoxylamine A (VAA). Tomato plants (cv. Odoriko) were sprayed with VMA or VAA at $100 \mu \mathrm{g} / \mathrm{ml} 28$ days after seeding. Leaves ( 1 to $2 \mathrm{~g}$ ) were boiled for $10 \mathrm{~min}$ after addition of $10 \times$ volume of $2 \%$ acetic acid ( $\mathrm{pH}$ 2.7). Three samples from three plants each were used for SA quantification. Free SA was detected with a UV detector at $245 \mathrm{~nm}$. SA was not detected in water-sprayed tomato leaves. The experiments were repeated three times with similar results.

TABLE 3. Effect of validamycin A (VMA) or validoxylamine A (VAA) on colony diameter of Fusarium oxysporum f. sp. lycopersici isolate 880621a-1

\begin{tabular}{|c|c|c|c|c|c|}
\hline \multirow[b]{2}{*}{ Medium } & \multirow{2}{*}{$\frac{\text { Control }}{\text { Mycelial growth }(\mathrm{mm})^{\mathrm{y}}}$} & \multicolumn{2}{|c|}{ VMA } & \multicolumn{2}{|c|}{ VAA } \\
\hline & & Mycelial growth (mm) & Inhibition (\%) & Mycelial growth (mm) & Inhibition (\%) \\
\hline PDA & 39.0 & $36.7 \mathrm{~ns}$ & 5.4 & $36.6 \mathrm{~ns}$ & 5.8 \\
\hline Water agar & 29.6 & $28.9 \mathrm{~ns}$ & 2.3 & $28.3 \mathrm{~ns}$ & 3.9 \\
\hline Czapek-trehalose ${ }^{\mathrm{z}}$ & 39.9 & $37.8 \mathrm{~ns}$ & 5.7 & $36.5 \mathrm{~ns}$ & 8.3 \\
\hline Czapek-sucrose ${ }^{z}$ & 41.9 & $40.4 \mathrm{~ns}$ & 3.3 & $39.2 \mathrm{~ns}$ & 6.3 \\
\hline Czapek-glucose ${ }^{\mathrm{z}}$ & 39.5 & $39.8 \mathrm{~ns}$ & -0.6 & $39.9 \mathrm{~ns}$ & -0.97 \\
\hline
\end{tabular}

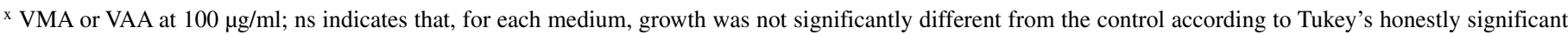
difference $(P<0.05)$.

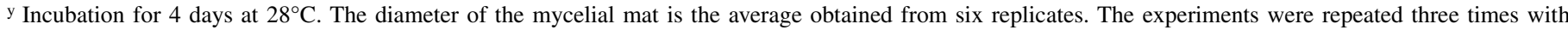
similar results. Data represent means of three separate experiments.

z $0.1 \%$ (wt/vol) carbohydrate. 
F. oxysporum f. sp. lycopersici is controlled at a site other than in roots.

Fusarium wilt shows symptoms 21 to 28 days after inoculation, and it is difficult to identify the time of infection. To examine the

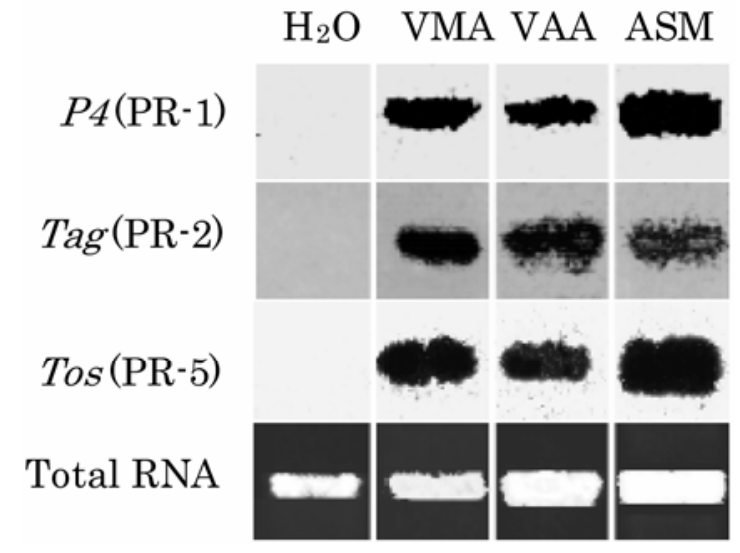

Fig. 4. RNA blot analysis of systemic acquired resistance marker gene expression in tomato leaves treated with validamycin A (VMA) or validoxylamine A (VAA). Leaves of tomato plants (cv. Odoriko) were sprayed with $\mathrm{H}_{2} \mathrm{O}$, VMA or VAA at $100 \mu \mathrm{g} / \mathrm{ml}$, or acibenzolar- $S$-methyl (ASM) at $125 \mu \mathrm{g} / \mathrm{ml}$. Leaves were collected 7 days after application. Each lane was loaded with $2 \mu \mathrm{g}$ of total RNA. The experiments were repeated three times with similar results. relationship between the time of application of VMA and induction of resistance, the tomato powdery mildew pathosystem was used. VMA spray needed at least 4 days to induce resistance (Table 5). The relationship between this disease control and the enhancement of SA accumulation from 3 days after treatment (Fig. 3) suggest that VMA was a SAR inducer. To evaluate whether the efficacy of VMA against Fusarium wilt could be attributed to SAR, we are conducting further studies on whether free or conjugated SA are accumulated in roots of treated tomato. Moreover, we are analyzing whether a spray of VMA would control the disease in $N a h G$ tomato plants in which SA hydroxylase is overexpressed and degrades SA. If VMA controlled Fusarium wilt in NahG tomato plants, the mode of action of VMA against Fusarium wilt could be other than SAR which is mediated by SA.

Plant activators such as PBZ, ASM, and harpin are protective against a number of pathogens $(2,17,20,39,44)$. In this study, VMA effectively controlled foliar diseases of tomato such as powdery mildew and late blight in addition to Fusarium wilt. Moreover, we already have reported that VMA is effective against diseases caused by fungi or bacteria on various crops (12-14). This broad spectrum of activity supports the hypothesis that VMA functions as a plant activator.

On media containing trehalose as the sole carbohydrate source, VMA or VAA at $100 \mu \mathrm{g} / \mathrm{ml}$ did not inhibit the mycelial growth of $F$. oxysporum f. sp. lycopersici (Table 4). This finding demonstrates that $F$. oxysporum f. sp. lycopersici is able to metabolize

TABLE 4. Control of powdery mildew or late blight of tomato by foliar spray of validamycin A (VMA)w

\begin{tabular}{|c|c|c|c|c|c|c|c|c|}
\hline \multirow[b]{3}{*}{ Treatment } & & & \multicolumn{6}{|c|}{ Late blight ${ }^{\mathrm{y}}$} \\
\hline & \multicolumn{2}{|c|}{ Powdery mildew ${ }^{x}$} & \multicolumn{2}{|c|}{ Experiment 1} & \multicolumn{2}{|c|}{ Experiment 2} & \multicolumn{2}{|c|}{ Experiment 3} \\
\hline & Dis. area $(\%)$ & Protection (\%) & Dis. area $(\%)$ & Protection (\%) & Dis. area $(\%)$ & Protection (\%) & Dis. area $(\%)$ & Protection (\%) \\
\hline Mock & $9.44 \mathrm{~b}$ & $\ldots$ & $66.7 \mathrm{~b}$ & $\ldots$ & $47.8 \mathrm{~b}$ & $\ldots$ & $86.7 \mathrm{~b}$ & $\ldots$ \\
\hline VMA & & & & & & & & \\
\hline$(10 \mu \mathrm{g} / \mathrm{ml})$ & $0.0 \mathrm{a}$ & 100 & $\ldots$ & $\ldots$ & $\ldots$ & $\ldots$ & $\ldots$ & $\ldots$ \\
\hline$(100 \mu \mathrm{g} / \mathrm{ml})$ & $\ldots$ & $\ldots$ & $26.7 \mathrm{a}$ & 60.0 & $17.2 \mathrm{a}$ & 64.0 & $23.9 \mathrm{a}$ & 72.4 \\
\hline VAA $(100 \mu \mathrm{g} / \mathrm{ml})^{\mathrm{z}}$ & $\ldots$ & $\ldots$ & $20.0 \mathrm{a}$ & 70.0 & $12.7 \mathrm{a}$ & 73.2 & $21.1 \mathrm{a}$ & 75.6 \\
\hline Trehalose $(100 \mu \mathrm{g} / \mathrm{ml})$ & $\ldots$ & $\ldots$ & $66.7 \mathrm{~b}$ & 0.0 & $48.9 \mathrm{~b}$ & -2.3 & $82.2 \mathrm{~b}$ & 5.1 \\
\hline
\end{tabular}

${ }^{w}$ For each column, different letters after the numbers represent significant differences according to Tukey's honestly significant difference $(P<0.05)$.

${ }^{\mathrm{x}}$ Tomato plants (cv. Odoriko) were sprayed to run off with VMA solution twice (14 and 28 days after seeding). Six plants with three replicates were used. Powdery mildew caused by Oidium spp. occurred by natural infection. The visible disease area (Dis. area) with symptoms was rated from 0 to $100 \%$ in $5 \%$ increments 10 days after inoculation, the ratio of the diseased area to healthy area on the third to eighth leaves was recorded 64 days after seeding, and the average ratio of diseased area was calculated.

${ }^{y}$ Seven days after a spray of VMA on 28-day-old tomato plants (cv. Odoriko) to run off, one drop of sporangium suspension $\left(1 \times 10^{4}\right.$ sporangia/ml) of Phytophthora infestans was placed on the first leaf. Inoculated tomato plants then were grown at $20^{\circ} \mathrm{C}$ in a high-humidity chamber for 14 days. The ratio of diseased area to the total leaf area was estimated from 0 to $100 \%$ in 5\% increments. In each plot, at least eight plants were used. The experiments were repeated three times with similar results.

${ }^{\mathrm{z}} \mathrm{VAA}=$ validoxylamine $\mathrm{A}$.

TABLE 5. Control of tomato powdery mildew days after a foliar spray of validamycin A (VMA)y

\begin{tabular}{|c|c|c|c|c|c|c|}
\hline \multirow[b]{2}{*}{ Chemical, $\mathrm{DBI}^{\mathrm{Z}}$} & \multicolumn{2}{|c|}{ Experiment 1} & \multicolumn{2}{|c|}{ Experiment 2} & \multicolumn{2}{|c|}{ Average } \\
\hline & Disease area $(\%)$ & Protection $(\%)$ & Disease area $(\%)$ & Protection $(\%)$ & Disease area $(\%)$ & Protection (\%) \\
\hline Mock & $83.0 \mathrm{~d}$ & $\ldots$ & $85.3 \mathrm{~d}$ & $\ldots$ & $84.2 \mathrm{~b}$ & $\ldots$ \\
\hline \multicolumn{7}{|l|}{ VMA } \\
\hline 7 & $4.8 \mathrm{a}$ & 94.2 & $2.0 \mathrm{a}$ & 97.7 & $3.4 \mathrm{a}$ & 96.0 \\
\hline 5 & $7.3 \mathrm{a}$ & 91.2 & $5.3 \mathrm{a}$ & 93.8 & $6.3 \mathrm{a}$ & 92.5 \\
\hline 4 & $2.7 \mathrm{a}$ & 96.8 & $5.0 \mathrm{a}$ & 94.1 & $3.8 \mathrm{a}$ & 95.4 \\
\hline 3 & $60.0 \mathrm{bcd}$ & 27.7 & $43.0 \mathrm{~b}$ & 49.6 & $51.5 \mathrm{~b}$ & 38.8 \\
\hline 2 & $59.2 \mathrm{bcd}$ & 28.7 & $49.4 \mathrm{bc}$ & 42.0 & $54.3 \mathrm{~b}$ & 35.5 \\
\hline 1 & $78.8 \mathrm{~cd}$ & 5.1 & $61.3 \mathrm{bcd}$ & 28.1 & $70.0 \mathrm{~b}$ & 16.8 \\
\hline \multicolumn{7}{|l|}{ Trehalose } \\
\hline 7 & $48.0 \mathrm{bc}$ & 42.2 & $65.0 \mathrm{bcd}$ & 23.8 & $56.5 \mathrm{~b}$ & 32.9 \\
\hline 5 & $84.7 \mathrm{~d}$ & -2.0 & $70.0 \mathrm{bcd}$ & 17.9 & $77.3 \mathrm{~b}$ & 8.1 \\
\hline 2 & $76.0 \mathrm{~cd}$ & 8.4 & $64.4 \mathrm{bcd}$ & 24.5 & $70.2 \mathrm{~b}$ & 16.6 \\
\hline 1 & $88.8 \mathrm{~d}$ & -6.9 & $67.0 \mathrm{bcd}$ & 21.5 & $77.9 \mathrm{~b}$ & 7.5 \\
\hline
\end{tabular}

y For each column, different letters after the numbers represent significant differences according to Tukey's honestly significant difference $(P<0.05)$.

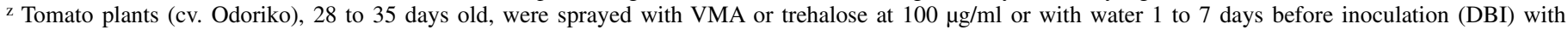
conidia of Oidium spp. The disease area of the leaf was estimated from the symptom of disease on the first to fifth leaves in $5 \%$ increments 10 days after inoculation. In each treatment, at least eight plants were used. 
trehalose using a pathway other than the trehalase pathway (e.g., trehalose phosphorylase or trehalose-6-phosphatase) $(25,40)$. Thus, VMA and VAA are not inhibitors of trehalase in $F$. oxysporum $\mathrm{f}$. sp. lycopersici, and trehalose may not be the sole transportable carbohydrate in $F$. oxysporum f. sp. lycopersici. In contrast, VMA at $20 \mu \mathrm{g} / \mathrm{ml}$ inhibited $90 \%$ of the hyphal growth of $R$. solani in media containing trehalose as the sole carbohydrate source because trehalose is the sole transportable carbohydrate in $R$. solani (33).

Recently, trehalose $(10 \mu \mathrm{g} / \mathrm{ml})$ has been reported to induce resistance to powdery mildew in wheat (29), and its accumulation confers a high tolerance level to abiotic stresses such as salt and drought (9). Trehalose plays an important role in response to stresses. In this study, a spray of trehalose at $100 \mu \mathrm{g} / \mathrm{ml}$ did not control late blight and powdery mildew of tomato (Tables 4 and 5). Thus, trehalose may not act to induce resistance in tomato plants.

Treatment of VMA or VAA sometimes reduces aspects of plant growth such as the length of petioles (Table 2) and plant height (Fig. 1C), phenomena which are similar to that of some constitutive expression of $P R$ genes (cpr) mutants of $A$. thaliana that showed dwarf phenotypes (3). Inhibition of plant growth with a treatment of VMA or VAA may be due to the enhancement of $P R$ genes expression; in other words, overexpression of $P R$ genes may result in shortage of nutrition for plant growth. Preliminary results indicate that, when the tomato plants were supplied with sufficient nutrition, VMA at $100 \mu \mathrm{g} / \mathrm{ml}$ did not inhibit their growth in a pot test (R. Ishikawa, unpublished data). SAR-induced plants may require more nutrients than do non-SAR-induced plants, which would result in a subsequent shortage of nutrients at the elongating meristems and, thus, result in growth inhibition. Trehalose signaling inhibits nitrogen and carbon assimilation (24). Trehalose accumulated in tomato plants by inhibition of trehalase with VMA or VAA might change carbohydrate metabolism. Biochemical changes other than a classical SAR effect may be influencing the development of disease because VMA, through trehalase inhibition, may have multiple effects on the plants.

A foliar spray of VMA or VAA on tomato seedlings in a nursery may be effective for the control of Fusarium wilt after the seedlings were transplanted into infested field soil. For disease control throughout the production cycle of tomato, a few additional sprays might be needed in the field, or VMA could be used in combination with other disease control measures in an integrated pest management program. The foliar spray of VMA and VAA represents a novel, convenient, and environmentally sound way to control soilborne diseases. By using VMA and VAA, it may become possible to reduce the use of more toxic pesticides.

\section{ACKNOWLEDGMENTS}

This research was partly supported by a Grant-in-Aid for Scientific Research from the Ministry of Education, Culture, Sports, Science and Technology of Japan (for T. Arie) and by a grant from the Interdisciplinary Research Institute of Environmental Sciences, Atami, Shizuoka, Japan (for T. Arie). We thank Y. Hosobuchi, Satake Seed, Yokohama, Japan and Musashi Seed, Nerima, Tokyo for $F$. oxysporum f. sp. lycopersici race $3 \mathrm{~F}-1-1$ and tomato seed.

\section{LITERATURE CITED}

1. Asano, N., Yamaguchi, T., Kameda, Y., and Matsui, K. 1987. Validamycins as trehalase inhibitors. J. Antibiot. 40:526-532.

2. Benhamou, N., and Belanger, R. 1998. Benzothiadiazole-mediated induced resistance to Fusarium oxysporum f. sp. radicis-lycopersici in tomato. Plant Physiol. 118:1203-1212.

3. Bowllng, S. A., Guo, A., Cao, H., Gordon, A. S., Klessig, D. F., and Dong, X. 1994. A mutation in Arabidopsis that leads to constitutive expression of systemic acquired resistance. Plant Cell 6:1845-1857.

4. Chitwood, D. E., and Deshusses, M. A. 2001. Development of a methyl bromide collection system for fumigated farmland. Environ. Sci. Technol. 35:636-642.
5. Church G. M., and Gilbert, W. 1984. Genomic sequencing. Proc. Natl. Acad. Sci. USA 81:1991-1995.

6. Durner, J., Shah, J., and Klessig, D. F. 1997. Salicylic acid and disease resistance in plants. Trends Plant Sci. 2:266-274.

7. Eastmond, P. J., and Graham, I. A. 2003. Trehalose metabolism: A regulatory role for trehalose-6-phosphate? Curr. Opin. 6:231-235.

8. Ezura, H., Nukui, N., Yuhashi, K.-I., and Minamisawa, K. 2000. In vitro plant regeneration in Macroptilium atropurpureum, a legume with a broad symbiont range for nodulation. Plant Sci. 159:21-27.

9. Garg, A. K., Kim, J., Owens, T. G., Ranwala, A. P., Choi, Y. D., Kochian, L. V., and Wu, R. J. 2002. Trehalose accumulation in rice plants confers high tolerance levels to different abiotic stresses. PNAS 99:15898-15903.

10. Görlach, J., Volrath, S., Knauf-Beiter, G., Hengy, G., Beckhove, U., Kogel, K., Oostendorp, M., Staub, T., Ward, E., and Kessmann, H. 1996. Benzothiadiazole, a novel class of inducers of systemic acquired resistance, activates gene expression and disease resistance in wheat. Plant Cell 8:629-643.

11. Hijwegen, T., and Termorshuizen, A. J. Z. 2000. Retarded development of Verticillium wilt in eggplant after application of Bion or Oryzalin. Z. Pflanzenkrankh. Pflanzenschutz 104:267-273.

12. Ishikawa, R. 1996. Antibacterial activity of validamycin A against some types of plant pathogenic bacteria. Plant Prot. (Shokubutsu Boeki). 50:422-425. (In Japanese)

13. Ishikawa, R., Fujimori, K., and Matsuura, K. 1996. Antibacterial activity of validamycin A against Pseudomonas solanacearum and its efficacy against tomato bacterial wilt. Ann. Phytopathol. Soc. Jpn. 62:478-482.

14. Ishikawa, R., Suzuki-Nishimoto, M., Fukuchi, A., and Matsuura, K. 2004. Effective control of cabbage black rot by validamycin A and its effect on extracellular polysaccharide-production of Xanthomonas campestris pv. campestris. J. Pestic. Sci. 29:209-213.

15. Kashimoto, K., Matsuda, Y., Matsutani, K., Sameshima, T., Kakutani, K., Nonomura, T., Okada, K., Kusakari, S., Nakata, K., Takamatsu, S., and Toyoda, H. 2003. Morphological and molecular characterization for a Japanese isolate of tomato powdery mildew Oidium neolycopersici and its host range. J. Gen. Plant Pathol. 69:176-185.

16. Kawabe, M., Mizutani, K., Yoshida, T., Teraoka, T., Yoneyama, K., Yamaguchi, I., and Arie, T. 2004. Cloning pathogenicity-related gene, FPD1, in Fusarium oxysporum f. sp. lycopersici. J. Gen. Plant Pathol. 70:16-20.

17. Kessmann, H., Staub, T., Hofmann, C., Maetzke, T., and Herzog, J. 1994. Induction of systemic acquired disease resistance in plants by chemicals. Annu. Rev. Phytopathol. 32:439-459.

18. King, G. J., Turner, V. A., Hussy, C. E., Jr., Wurtele, E. S., and Lee, S. M. 1988. Isolation and characterization of a tomato cDNA clone which codes for a salt-induced protein. Plant Mol. Biol. 10:401-412.

19. Kobayashi, Y., Arie, T., Shibasaki, M., and Yamaguchi, I. 1997. 4-Allyl-2azetidinone and Penicillium simplicissimum cooperate to control soilborne Fusarium diseases. J. Pestic. Sci. 22:113-118.

20. Latunde-Dada, A. O., and Lucas, J. A. 2001. The plant defense activator ASM primes cowpea [Vigna unguiculata (L.) Walp.] seedlings for rapid induction of resistance. Physiol. Mol. Plant Pathol. 58:199-208.

21. Malamy, J., Sánchez-Casas, P., Hennig, J., Guo, A., and Klessig, D. F. 1996. Dissection of the salicylic acid signaling pathway in tobacco. Mol. Plant-Microbe Interact. 6:474-482.

22. Midoh, N., and Iwata, M. 1996. Cloning and characterization of a probenazole-inducible gene for an intracellular pathogenesis-related protein in rice. Plant Cell Physiol. 37:9-18.

23. Misaghi, I., and Grogan, R. G. 1969. Nutritional and biochemical comparison of plant-pathogenic and saprophytic fluorescent pseudomonads. Phytopathology 59:1436-1450.

24. Morcuende, R., Kostadinova, S., Perez, P., Martin del Molino, I. M., and Martinez-Carrasco, R. 2004. Nitrate is a negative signal for fructan synthesis, and the fructosyltransferase-inducing trehalose inhibits nitrogen and carbon assimilation in excised barley leaves. New Phytol. 161:749-759.

25. Müller, J., Aeschbacher, R. A., Wingler, A., Boller, T., and Wiemken, A. 2001. Trehalose and trehalase in Arabidopsis. Plant Physiol. 125:10861093.

26. Nakayama, M., Matsuura, K., and Okuno, T. 1996. Production of salicylic acid in tobacco and cowpea plants by systemic fungicide ferimzone and induction of resistance to virus infection. J. Pestic. Sci. 21:69-72.

27. Ohata, K., Araki, T., Kiso, A., Kudo, A., and Takahashi, K. (eds.) 1995. Bases on the Technique for the Study of Plant Pathogens. Japan Plant Protection Association, Tokyo. (In Japanese)

28. Oostendorp, M., Kunz, W., Dietrich, B., and Staub, T. 2001. Induced disease resistance in plants by chemicals. Eur. J. Plant Pathol. 107:19-28.

29. Reignault, P., Cogan, A., Muchembled, J., Lounes-Hadj Sahraoui, A., Durand, R., and Sancholle, M. 2001. Trehalose induces resistance to powdery mildew in wheat. New Phytol. 149:519-529. 
30. Ryals, J. A., Neuenschwander, U. H., Willits, M. G., Molina, A., Steiner, H., and Hunt, M. D. 1996. Systemic acquired resistance. Plant Cell 8:1809-1819.

31. Schluepmann, H., Pellny, T., van Dijken, A., Smeekens, S., and Paul, M. 2003. Trehalose 6-phosphate is indispensable for carbohydrate utilization and growth in Arabidopsis thaliana. PNAS 100:6849-6854.

32. Shigemoto, R., Okuno, T., and Matsuura, K. 1989. Effect of validamycin A on the activity of trehalase of Rhizoctonia solani and several sclerotial fungi. Ann. Phytopathol. Soc. Jpn. 55:238-241.

33. Shigemoto, R., Okuno, T., and Matsuura, K. 1992. Effect of validamycin A on the growth of and trehalose content in mycelia of Rhizoctonia solani incubated in a medium containing several sugars as the sole carbon source. Ann. Phytopathol. Soc. Jpn. 58:685-690.

34. Sticher, L., Mauch-Mani, B., and Metraux, J. P. 1997. Systemic acquired resistance. Annu. Rev. Phytopathol. 35:235-270.

35. Tomlin, C. D. S. (ed.) 1997. The Pesticide Manual, 11th ed. British Crop Protection Council, Surrey, UK

36. United Nations Environment Programme, Industry and Environment. 1998. Methyl bromide: getting ready for the phase out. UNEP, Paris.

37. Van Kan, J. A., Joosten, M. H., Wagemakers, C. A., Van Den BergVelthuis, G. C., and De Wit, P. J. 1992. Differential accumulation of mRNAs encoding extracellular and intracellular PR proteins in tomato induced by virulent and avirulent races of Cladosporium fulvum. Plant Mol. Biol. 20:513-527.
38. Wakae, O., and Matsuura, K. 1975. Characteristic of validamycin as a fungicide for Rhizoctonia disease control. Rev. Plant Prot. Res. 8:81-92.

39. Wei, Z., Laby, R. J., Zumoff, C. H., Bauer, D. W., He, S. Y., Collmer, A., and Beer, S. V. 1992. Harpin, elicitor of the hypersensitive response produced by the plant pathogen Erwinia amylovora. Science 257:85-88.

40. Wingler, A., Fritzius, T., Wiemken, A., Boller, T., and Aeschbacher, R. 2000. Trehalose induces the ADP-glucose pyrophosphorylase gene, APL3, and starch synthesis in Arabidopsis. Plant Physiol. 124:105-114.

41. World Meteorological Organization with National Oceanic and Atmospheric Administration, National Aeronautics and Space Administration, United Nations Environment Program, and the European Commission. 1998. Scientific Assessment of Ozone Depletion. World Meteorological Organization Global Ozone Research and Monitoring Project Report 44.

42. Yang, Y., Shah, J., and Klessig, D. F. 1997. Signal perception and transduction in plant defense responses. Genes Dev. 11:1621-1639.

43. Yasuda, M., Nakashita, H., Hasegawa, S., Nishioka, M., Arai, Y., Uramoto, M., Yamaguchi, I., and Yoshida, S. 2003. N-Cyanomethyl-2chloroisonicotinamide induces systemic acquired resistance in Arabidopsis without salicylic acid accumulation. Biosci. Biotechnol. Biochem. 67:322-328.

44. Yoshioka, K., Nakashita, H., Klessig, D. F., and Yamaguchi, I. 2001 Probenazole induces systemic acquired resistance in Arabidopsis with a novel type of action. Plant J. 25:149-158. 